\title{
Cretaceous stage boundaries in the southern Interior Plains of Canada
}

\author{
W. G. E. CALDWELL AND B. R. NORTH
}

\begin{abstract}
Caldwell, W. G. E. and North, B. R.: Cretaceous stage boundaries in the southern Interior Plains of Canada. Bull. geol. Soc. Denmark, vol. 33, pp. 57-69, Copenhagen, September, 10th, 1984. https://doi.org/10.37570/bgsd-1984-33-05

Marine Cretaceous rocks of Berriasian to Aptian age are restricted to northwestern Alberta and north-eastern British Columbia where many stage and substage boundaries may be drawn only tentatively on the basis of limited molluscan faunas. A complete marine Albian succession is similarly restricted, although the middle and upper divisions of the stage are much more widespread. The complete Albian succession of the Peace River district contains a refined and well-documented sequence of ammonite and foraminiferal zones and would be a most suitable continental standard.

The Albian-Cenomanian (Lower-Upper Cretaceous) boundary has been reliably established in the continuous foraminifer- and mollusc-bearing sequences of the northwestern plains, but eastward it becomes enclosed in a hiatus. The same is true of successive stage boundaries from the CenomanianTuronian to the Santonian-Campanian. The bases for establishment of these boundaries, therefore, can be fully considered only on the western flank of the basin. The Campanian-Maastrichtian boundary may be precisely drawn in western Saskatchewan and traced westward to the Rocky Mountain front.

Zones based on ammonites and inoceramid bivalves form the cornerstone of the biostratigraphy and chronostratigraphy of the southern Interior Plains and hold the key to the stage boundaries. Zones based on assemblages of benthonic foraminifers, rarely of planktonic foraminifers, supplement the molluscan zones. The foraminiferal zones are less reliable and less useful, however, because some benthonic assemblages are weakly diachronous, most foraminiferal zones span several molluscan zones, and many stage boundaries fall within individual foraminifer zones.
\end{abstract}

W. G. E. Caldwell and B. R. North, Department of Geological Sciences, University of Saskatchewan, Saskatoon, Saskatchewan, Canada, S7N OWO, April 11th, 1984.

\section{Zones and stages}

Molluscan fossils, particularly ammonites and inoceramid bivalves, form the cornerstone of zonal schemes for Cretaceous rocks in most parts of the world. Nowhere have these fossils been used with greater effect biostratigraphically and chronostratigraphically than in the Western Interior basin of North America. Having been described for well over one hundred and fifty years, they are now sufficiently well known to allow recognition of more than sixty reliably tested biozones in the Upper Cretaceous Series alone. Although the North American Code of Stratigraphic Nomenclature (1983) suggests a clear distinction between such zones, which are biostratigraphic divisions, and stages, which are chronostratigraphic divisions, the two are intimately related; zones form the basis of the relative time-scale used in the basin, and boundaries between stages are drawn in the original d'Orbignyan sense to coincide with boundaries between zones.
Kaufmann et al. (1977, p. 12) demonstrated that sections within the Western Interior of the United States permit precise delineation of certain stage and substage boundaries and proposed that these and other sections be considered important reference sections in any attempt to finalize definition of the inter-stage boundaries originally defined in Europe. The portion of the Western Interior basin in the United States unquestionably offers the best sections for the establishment of regional (if not international) standards for most of the Upper Cretaceous Series. Only in the Canadian portion of the Western Interior basin, however, do sections exist in marine facies suitable for the establishment of similar standards through the Lower Cretaceous Series. The Peace River district of northwestern Alberta and northeastern British Columbia, in particular, offers an unmatched section through the Albian Stage into the Cenomanian Stage and must be given further consideration as a standard for (at least) the continent. The purpose of this 
summary, therefore, is to offer a synopsis of how inter-stage boundaries currently are discriminated in marine sections of the southern Interior Plains of Canada and to identify segments of the basin that may warrant further study in the interests of better defining stages and substages for continental and intercontinental correlation.

The Western Interior basin and the epeiric sea that occupied it throughout most of the Cretaceous Period were of truly continental proportions. When most widespread, the Western Interior seaway extended in length some $4800 \mathrm{~km}$, linking what is now the Beaufort Sea and the Gulf of Mexico, and in width some $1600 \mathrm{~km}$, from what is now Utah to Iowa. Composition of the molluscan faunas and of other elements of the biotas were not uniform throughout so vast a seaway, and variations in the composition are attributable to two main factors. Firstly, once the seaway was established, faunas of northern and of southern provenance migrated so deeply into the basin that a broad and fluctuating zone of overlap was established between them. That zone became an important endemic centre (Kauffman 1973 , p. 368 , fig. $2 ; 1977$, p. 96). Secondly, a northward declining palaeo-temperature gradient, based on oxygen-isotope measurements, has been established, and the geographic grid for the entire basin has been reconstructed from palaeomagnetic measurements of polar position. Superimposed, gradient and grid reveal a gradual decrease in palaeotemperature with increase in palaeolatitude and offer support for the longheld, but hitherto unsubstantiated, view that northward decline in the number and variety of molluscs and other biotic elements could be attributed to palaeolatitudinal (and therefore palaeoclimatic) variation (Caldwell 1982, p. 301303). The existence of two biogeographical provinces within the basin, one of northern or 'Boreal' ancestry, the other of southern or 'gulfian' ancestry, long has been recognized. These now have been formalized as the North American Interior Subprovince, which generally extends southward through Wyoming, and the Southern Interior Subprovince, which generally extends northward through Colorado. Both are components of the North American Province and lie within the global North Temperate Realm (Kauffman 1973). Differences in the faunas of the biogeographical subprovinces find expression in somewhat different zonal schemes for the northern (Canadian) and southern (United States) portions of the basin. The sequence of molluscan zones applied in the United States has been compiled and refined mainly by W. A. Cobban of the United States Geological Survey. It has been published widely. Particularly pertinent to this contribution is the version by Cobban (in Obradovich and Cobban 1975, tab. 1) in which ammonite zones and isotopic ages are related to the discrimination of stage boundaries. Kauffman et al. $(1977$, p. $7-12)$ have described in detail their zones and their concept of the stages and substages from Late Albian to Late Coniacian in the Western Interior of the United States. The sequence of molluscan zones applied in Canada has been compiled mainly by J. A. Jeletzky of the Geological Survey of Canada. The basis for the biostratigraphic framework is discussed by Jeletzky (1968) and a good tabular summary is available in Jeletzky (1971, fig. 3). Illustrations of the more important molluscan species may be found in Jeletzky $(1964,1970)$. Kauffman (1979, figs 3B,E, 4B,E) has outlined a zonal framework for the Arctic and Western Interior of North America that draws heavily on Cobban's and Jeletzky's schemes.

In the last thirty years, attempts have been made to complement the molluscan zonal sequences with those based on foraminifers. A foraminiferal biostratigraphic framework for much of the Cretaceous System in the Western Interior of the United States may be compiled mainly from the contributions of Eicher (1960, 1965, 1966, 1967, in Kaufmann et al. 1977) and Eicher and Worstell (1970), and a preliminary framework of zones for the southern Interior Plains of Canada is available (Caldwell et al. 1978). Difficulties with the foraminiferal zonal schemes arise because so many of the zonal assemblages are composed of agglutinated or mixed agglutinated and calcareous benthonic elements, and the chronostratigraphic reliability of many of these assemblages for correlation has not yet been sufficiently tested. Assemblages dominated by planktonic elements are comparatively rare and, throughout much of the basin, lack the keeled species proven elsewhere to have the greatest chronostratigraphic reliability. Nonetheless, the foraminiferal zones are particularly useful in the southern Interior Plains of Canada (fig. 1), where 


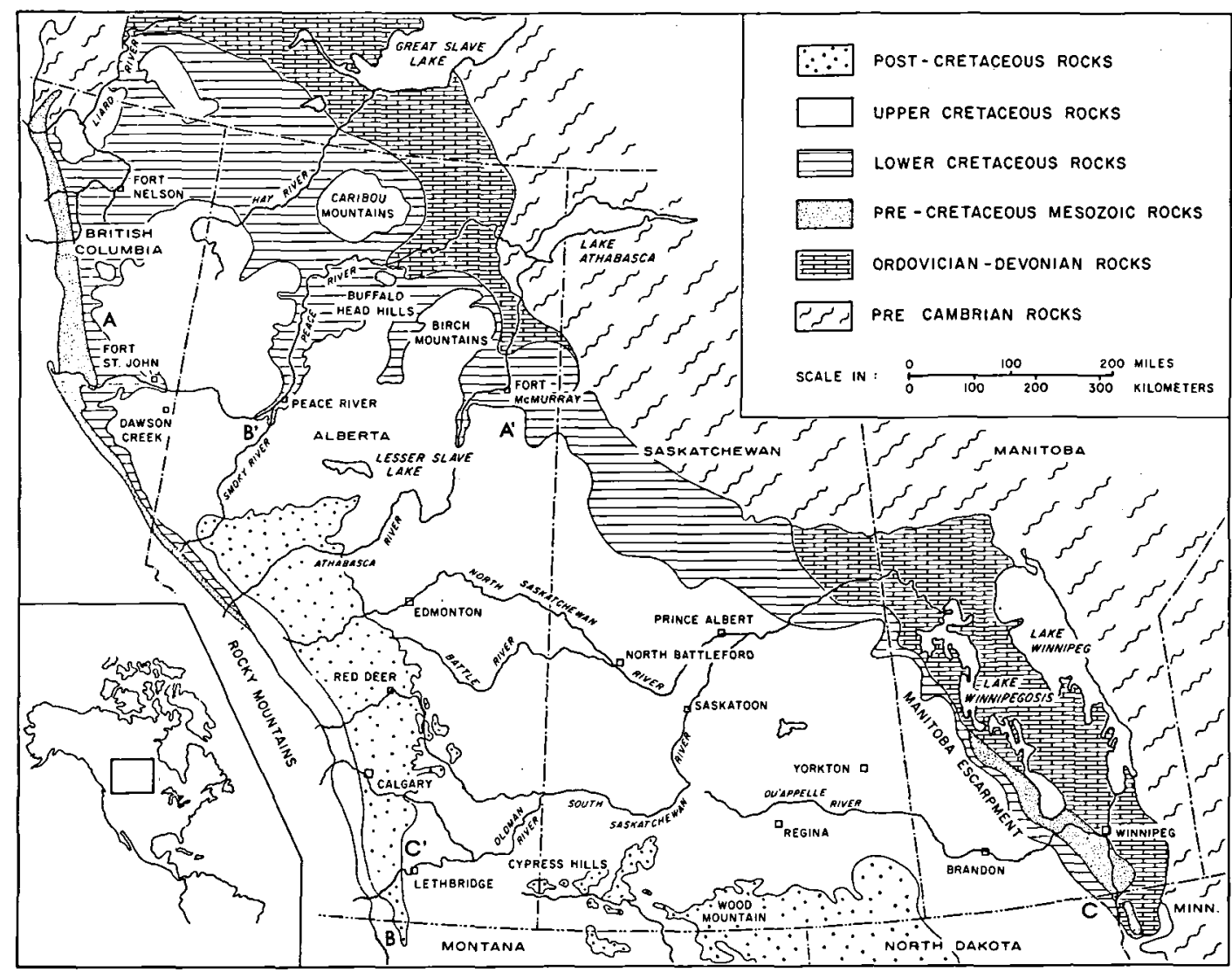

Figure 1. Geological sketch map of the southern Interior Plains of Canada to show the distribution of Lower and Upper Cretaceous rocks and the principal geographical localities.

Cretaceous rocks are largely buried beneath glacial deposits of Pleistocene age, where many key sections have been cored in the subsurface, and where the yield of molluscs has been appreciably lower than in the interior plains of the United States.

Table 1 summarizes the position of inter-stage boundaries, as these are interpreted in the Western Interior of Canada, relative to the key molluscan zones and to the foraminiferal zones and subzones.

\section{Stage boundaries within the Lower Cretaceous Series}

Although rocks of Berriasian to Aptian age may be widely distributed in the southern Interior Plains of Canada (Rudkin 1964), these rocks are mainly in continental and marginal-marine facies and not amenable to dating by foraminiferal and molluscan fossils. Age (or stage) has been ascertained from palaeobotanical evidence or inferred by lithostratigraphic correlation with dated deposits in adjacent regions.

Only in the Rocky Mountain foothills and adjacent plains of northwestern Alberta and, particularly, northeastern British Columbia is the proportion of marine rocks in the Lower Cretaceous Series sufficient to warrant biostratigraphic analysis in terms of Jeletzky's molluscan zonal scheme. Even in this portion of the region broadly defined as the southern Interior Plains, however, the palaeontological grounds for identifying the stage and substage boundaries are weak, and many of the boundaries can be drawn only tentatively. Stott (1975) has summarized the variable sequences of this belt and 


\begin{tabular}{|c|c|c|c|c|}
\hline \multirow{2}{*}{\multicolumn{2}{|c|}{\begin{tabular}{|l} 
STAGES \\
PALEOCENE \\
\end{tabular}}} & \multirow[t]{2}{*}{$\begin{array}{c}\text { SELECTED } \\
\text { MOLLUSCAN ZONES }\end{array}$} & \multicolumn{2}{|c|}{ FORAMINIFERAL } \\
\hline & & & \multirow{2}{*}{\multicolumn{2}{|c|}{ NON-MARINE DEPOSITS }} \\
\hline \multirow{3}{*}{\multicolumn{2}{|c|}{ MAESTRICHTIAN }} & \multirow{3}{*}{$\begin{array}{l}\text { [Triceratops dinosaurs] } \\
\text { Baculites grandis } \\
\text { Baculites baculus } \\
\text { Baculites eliasi } \\
\text { Baculites jenseni } \\
\text { Baculites reesidei }\end{array}$} & & \\
\hline & & & $\begin{array}{r}\text { Haptophragmoides } \\
\text { excavata }\end{array}$ & \\
\hline & & & Anomatinoides sp. & . \\
\hline \multirow{4}{*}{\multicolumn{2}{|c|}{ CAMPANIAN }} & \multirow{4}{*}{$\begin{array}{l}\text { Baculites cuneatus } \\
\text { Baculites compressus } \\
\text { Didymoceras cheyennense } \\
\text { Exiteloceras jenneyi } \\
\text { Didymoceras stevensoni } \\
\text { Baculites gregoryensis } \\
\text { Baculites perplexus } \\
\text { Baculites asperiformis } \\
\text { Baculites macteami } \\
\text { Baculites obtusus } \\
\text { saculites sp. } \\
\text { Scaphites hippocrepis }\end{array}$} & $\begin{array}{r}\text { Haplophragmoides } \\
\text { fraseri }\end{array}$ & $\begin{array}{l}\text { Praebulimina kickapooensis } \\
\text { Gaudryina bearpawensis } \\
\text { Dorothia of. smokyensis }\end{array}$ \\
\hline & & & Eoeponidella linki & \\
\hline & & & Glomospira corona & $\begin{array}{l}\text { Quinqueloculina sphaera } \\
\text { Spiroplectanmina sigmoidina }\end{array}$ \\
\hline & & & $\begin{array}{l}\text { Trochammina } \\
\text { ribstonensis }\end{array}$ & \\
\hline \multirow{2}{*}{\multicolumn{2}{|c|}{ SANTONIAN }} & \multirow{2}{*}{\begin{tabular}{|l|} 
Desmoscaphites bassleri \\
Desmoscaphites endmanni \\
Clioscaphites choteauensis \\
clioscaphites vermiformis \\
Scaphites depressus
\end{tabular}} & Globigerinelloides sp. & $\begin{array}{l}\text { Heterohelix of. reussi } \\
\text { Gavelinelia henbesti }\end{array}$ \\
\hline & & & Bullopora Laevis & \\
\hline & CONIACIAN & \begin{tabular}{|l|} 
Saaphites ventricosus \\
Scaphites preventricosus
\end{tabular} & Trochamina sp. & \\
\hline \multirow{3}{*}{\multicolumn{2}{|c|}{ TURONIAN }} & \multirow{3}{*}{$\begin{array}{l}\text { Collignoniceras wooligari } \\
\text { Inoceramus labiatus } \\
\text { Watinoceras reesidei }\end{array}$} & Pseudoclavutina op. & \\
\hline & & & Hedbergella loetterlei & $\begin{array}{l}\text { Whiteinella aprica } \\
\text { Clavihedbergella simplex }\end{array}$ \\
\hline & & & \multirow{2}{*}{$\begin{array}{l}\text { Flabellamina } \\
\text { gteddiei }\end{array}$} & \multirow{2}{*}{$\begin{array}{l}\text { Haplophragmoides spiritense } \\
\text { Amobaculites pacalis }\end{array}$} \\
\hline \multirow{3}{*}{\multicolumn{2}{|c|}{ CENOMANIAN }} & \multirow{3}{*}{$\begin{array}{l}\text { Dunveganoceras hagei } \\
\text { Dunveganoceras of. parvun } \\
\text { Dunveganoceras albertense } \\
\text { Dunveganoceras of. conditun } \\
\text { Acanthoceras athabascense } \\
\text { Beattonoceras beattonense }\end{array}$} & & \\
\hline & & & $\begin{array}{l}\text { Verneuilinoides } \\
\text { perplexus }\end{array}$ & $\begin{array}{l}\text { Gaudryina irenensis } \\
\text { Armobaculites gravenori }\end{array}$ \\
\hline & & & Textularia alcesensis & \\
\hline \multirow{3}{*}{\multicolumn{2}{|c|}{ ALBIAN }} & $\begin{array}{l}\text { Neogastroplites macleami } \\
\text { Neogastroplites muelleri } \\
\text { Neogastroplites copnutus } \\
\text { Neogastroplites haasi } \\
\end{array}$ & $\begin{array}{l}\text { Miliammina } \\
\text { manitobensis }\end{array}$ & $\begin{array}{l}\text { Haplophragmium swareni } \\
\text { Haplophragmoides postis } \\
\text { goodrichi } \\
\text { Vermeuitina canadensis }\end{array}$ \\
\hline & & \multirow{3}{*}{$\begin{array}{l}\text { Inoceramus comancheanus } \\
\text { Stelckiceras liamdense } \\
\text { Gastroplites allani } \\
\text { Gastroptites kingi } \\
\text { Pseudopulchellia pattoni } \\
\text { Arcthoplites macconnelli } \\
\text { Arcthoplites irenense } \\
\text { Lemuroceras of. L. indicum } \\
\text { Cleoniceras cf. C. subbaylei } \\
\text { Fachygrycia spp. } \\
- \text { Absent } \\
\text { Aucellina of aptiensis- }\end{array}$} & Haptophragmoides gigas & \multirow[b]{2}{*}{$\begin{array}{l}\text { Armobaculites wenonahae } \\
\text { Amobaculites sp. } \\
\text { Haplophragmoides multiplum } \\
\text { Marginutinopsis collinsi- } \\
\text { Verneuilinoides oummingensis } \\
\text { Trochammina ncmurrayensis } \\
\text { Rectobolivina sp. }\end{array}$} \\
\hline & & & \multirow{7}{*}{ FORAMINIFE } & \\
\hline \multicolumn{2}{|r|}{ APTIAN } & & & \\
\hline \multirow{4}{*}{ 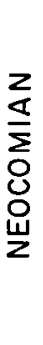 } & BARREMIAN & $\begin{array}{l}\text { Crioceratites of. c. lardii } \\
\text { Crioceratites of. } c . \text { notant } \\
\text { oxyteuthis of. } \\
\text { o. jasikowi }\end{array}$ & & RA POORLY KNOWN. \\
\hline & HAUTERIVIAN & $\begin{array}{l}\text { Craspedodiscus of. } \\
\text { discofalcatus } \\
\text { simbirskites of. S. kleini } \\
\text { Unnamed zone } \\
\text { Marine rocks unknown }\end{array}$ & & ET ESTABLISHED. \\
\hline & VALANGINIAN & $\begin{array}{l}\text { Buchia inflata } \\
\text { Buchia ef. B. keyeerlingi }\end{array}$ & & \\
\hline & BERRIASIAN & $\begin{array}{l}\text { Buchia n. sp. aff. B. volgensis } \\
\text { Buchia okensis }\end{array}$ & & \\
\hline & TITHONIAN & $\begin{array}{l}\text { Buchia fischeriana } \\
\text { Buchia piochii }\end{array}$ & & \\
\hline
\end{tabular}

Table 1. Summary of the international stages as these are recognized in the southern Interior Plains of Canada in relation to molluscan zones and to foraminiferal zones and subzones as established by Caldwell et al. (1978). To avoid excessive crowding, only a section of the molluscan zones are shown, but this includes all key zones for discrimination of the stage boundaries. For a full sequence of molluscan zones, see references cited in text. 
shown their correlation in terms of relative ages.

The Tithonian-Berriasian stage and inter-systemic boundary, together with the BerriasianValanginian and Valanginian-Hauterivian substage boundaries, are drawn within Jeletzky's (1968, p. 6-10, fig. 1; 1971, fig. 3) sequence of zones based mainly on Buchia. The boundary between the Buchia fischeriana Zone and the $B$. okensis Zone, the latter containing also Subcraspedites aff. $S$. suprasubditus, is regarded tentatively as the stage boundary; that between the $B$. n. sp. aff. $B$. volgensis Zone and the $B$. cf. $B$. keyserlingi Zone, the latter containing also Polyptychites cf. P. keyserlingi, is taken as the lower of the substage boundaries; and the top of the $B$. inflata Zone, where it is in contact with nonmarine rocks, is regarded as a close approximation of the upper of the substage boundaries (Stott 1975, text-fig. 3). The Berriasian and Valanginian ammonites, bivalves, and belemnites are of north Pacific affinity and suggest a connecting strait from the Peace River marine embayment, through the meso-Cordilleran uplift, to the western ocean (Jeletzky 1971, p. 35-38; Williams and Stelck 1975, p. 3, 4; Stott 1975, p. 447-449).

Hauterivian and Lower Barremian rocks generally are absent from northwestern Alberta and northeastern British Columbia, and the inference that the Hauterivian-Barremian boundary would coincide with that between the Zone of Craspedodiscus cf. C. discofalcatus and that of Crioceratites cf. $C$. nolani and Oxyteuthis cf. $O$. jasikowi is based on marine sections well to the north of the southern Interior Plains.

Like the lower boundary of the Berriasian Stage, the Barremian-Aptian boundary can only be placed questionably within the molluscan zonal sequence of Jeletzky; it lies within the Zone of Aucellina of the aptiensis-caucasica group (Stott 1975, text-fig. 3). More recent work implies a somewhat more precise position within this broad aucellinid zone, however; Stott (1982, fig. 5) showed it tentatively to lie within an unnamed subzone underlain by the Subzone of $A r-$ coteuthis (?) cf. A. mitchelli and A. kernensis and overlain by the Subzone of Tropaeum hillsi.

Foraminifera from the Berriasian-Barremian and Aptian sequences of the southern Interior Plains are poorly known and do not yet permit the establishment of a series of zones to supple- ment the molluscan zones. Chamney (1973, p. 67-72), recorded numerous foraminifers from the marine facies of the Barremian-Aptian Gething Formation in northeastern British Columbia, but his species (in Stott 1973, p. $146 \mathrm{ff}$.) are mainly nomina aperta and not illustrated. Hence it is impossible to assess his suggested zones and relate them either to the molluscan zones or to the post-Aptian foraminiferal zones of Caldwell et al. (1978).

Much better known in the southern Interior Plains than the Berriasian-Barremian and Aptian stages, the Albian Stage is substantially present in marine facies throughout the region and has an exceedingly thick and near-continuous development in northwestern Alberta and northeastern British Columbia. The stage records two major southward transgressions of the Boreal sea into the southern Interior Plains. The younger transgression - a phase of the Kiowa-Skull Creek marine cycle of Kauffman et al. (1977, p. 3, 4, fig. 2) and of the $T_{5}-R_{5}$ global cycle of Kauffman (1977, p. 89, fig. 7) - extended through the Western Interior of the United States to become confluent, early in Late Albian time, with a northward transgression of marine waters from the Gulf Coast to establish the Western Interior seaway. The Lower Albian is characterized by the Arcthoplites ammonite fauna, although this fauna makes its appearance above the base of the stage; the Middle Albian is distinguished by various gastroplitinid ammonites, with zones based on Pseudopulchellia pattoni, Gastroplites spp. (sensu stricto), and Stelckiceras ["Paragastroplites"] liardense; and the Upper Albian is identified by successive species of Neogastroplites.

Jeletzky and Stelck (1981, fig. 1) suggested that the Aptian-Albian boundary might be drawn coincident with base of the new Zone of Pachygrycia spp. It replaces the old Zone of Sonneratia cf. kitchini of Jeletzky $(1968,1971)$, overlies the broad Aptian zone distinguished by Aucellina of the aptiensis-caucasica species group, and underlies the Zone of Arcthoplites spp. An external homoeomorph of Sonneratia, the new ammonite genus, Pachygrycia, is a cleoniceratinid, referred to the desmoceratid family, and probably derived from a still-unknown, Boreal, beudanticeratinid stock. The Zone of Pachygrycia spp. is correlated with the lower part of the European basal Albian Zone of 
Leymeriella tardefurcata. The Pachygrycia fauna may be anticipated wherever basal Albian beds in marine facies are present in the southern Interior Plains. At present, however, it has been recorded only from the most northerly limit of this region (Jeletzky and Stelck 1981, p. 10, fig. 20).

Foraminiferal faunas do not assist in delimiting the Aptian-Albian boundary in the southern Interior Plains; the lowest zones in the preliminary zonal scheme of Caldwell et al. (1978) correspond to the Zone of Arcthoplites spp. in the ammonite scheme, and the foraminiferal fauna of the Zone of Pachygrycia spp. is unknown.

Jeletzky's (1980) and Jeletzky and Stelck's (1981) revision of the Albian molluscan zones and substage assignments in northwestern Canada, does, however, require some changes in the ages assigned to the foraminiferal zones of Caldwell et al. (1978, p. 502-519). The Gaudryina nanushukensis Zone now may be assumed to mark the sequence from early Early Albian through Middle Albian, with the Rectobolivina sp. Subzone being of early Early Albian Age, the Trochammina mcmurrayensis Subzone of middle Early Albian Age, the Marginulinopsis collinsiVerneuilinoides cummingensis Subzone of late Early Albian Age, the Haplophragmoides multiplum Subzone of early to middle Middle Albian Age, the Ammobaculites sp. Subzone of middle Middle Albian Age, and the Ammobaculites wenonahae Subzone of late Middle Albian Age. The widespread Haplophragmoides gigas Zone remains early Late Albian in age, but the equally widespread Miliammina manitobensis Zone must now be regarded as ranging from early to late Late Albian, with the Verneuilina canadensis Subzone as early to middle Late Albian in age, the Haplophragmoides postis goodrichi Subzone as middle Late Albian in age, and the Haplophragmium swareni Subzone as middle to late Late Albian in age. The Haplophragmoides gigas and $M$. manitobensis zones may be traced well into the Western Interior of the United States (Eicher 1960; in Kauffman et al. 1977, p. 7, 8, fig. 6). Save for a few elements appearing late in the stage, the Albian foraminifers and molluscs are exclusively Boreal in origin and belong to the North American Interior Subprovince.

\section{Albian-Cenomanian (Lower-Upper Cretaceous) boundary}

Across the southern Interior Plains of Canada, the Albian-Cenomanian boundary beds are sandy to silty and packed with fish scales. Collectively, these beds compose the fish-scale marker, the top of which usually is taken as the stage boundary. To read the boundary in such simplistic lithostratigraphic terms, however, ignores the complexities of the age relations.

Warren and Stelck $(1958,1969)$, working in the relatively continuous and thick sections of northwestern Alberta and northeastern British Columbia, laid the foundation for a detailed succession of ammonite zones through the Upper AlbianLower Cenomanian. Sequential species of Neogastroplites: $N$. haasi, $N$. cornutus, $N$. muelleri, $N$. americanus, $N$. maclearni, and $N$. septimus distinguish sequential subzones of the Neogastroplites Zone in the uppermost Albian-lowermost Cenomanian, and Irenicoceras bahani Warren and Stelck and Beattonoceras beattonense Warren and Stelck distinguish zones in the overlying Lower Cenomanian. Ammonites are unknown in the Lower Cenomanian of the Western Interior of the United States and exceedingly rare in the Western Interior of Canada. The Irenicoceras and Beattonoceras beds, therefore, are of unusual importance. Both genera are believed to be gastroplitinid derivatives (Warren and Stelck 1958, p. 38,41 ) and are inferred to be of Early Cenomanian Age because they occur in beds beneath those containing Middle to Late Cenomanian Acanthoceras and Dunveganoceras. According to Warren and Stelck (1969, p. 532), Neogastroplites maclearni is present in the 'fish-scale marker' of the Peace River valley. The slightly older $N$. americanus usually occurs just below the base of the marker, although at some localities the base may be as low as the $N$. americanus Subzone. Neogastroplitid ammonites have not been found eastwards across the plains of Saskatchewan or Manitoba where Upper AlbianLower Cenomanian rocks, if present, are buried in the subsurface; nor have they been found in outcrops of the Manitoba escarpment (McNeil and Caldwell 1981).

Three foraminiferal zones come under consideration in attempting to elucidate the nature and 
position of the Albian-Cenomanian boundary; these are the Miliammina manitobensis Zone of Late Albian Age, the Textularia alcesensis Zone of latest Albian and Early Cenomanian Age, and the Verneuilinoides perplexus Zone of Middle to Late Cenomanian Age. Most of the zonal elements, like so many of the molluscs, are Boreal or endemic in origin and belong to the North American Interior Subprovince. It is in the continuous and thick sedimentary sequences of northwestern Alberta and northeastern British Columbia that the $M$. manitobensis Zone is divisible into the Verneuilina canadensis Subzone (oldest), the Haplophragmoides postis goodrichi Subzone, and the Haplophragmium swareni Subzone (youngest) (Caldwell et al. 1978, p. 514519). The 'fish-scale marker' lies within the $T$. alcesensis Zone (Stelck et al. 1958, p. 20), which in terms of the ammonite zones spans the $N$. maclearni and $N$. septimus subzones of the Neogastroplites Zone and the overlying $I$. bahani Zone and $B$. beattonense Zone. Recognized in cored boreholes, the 'fish-scale marker' has been projected through the subsurface into eastern Saskatchewan and Manitoba (Williams and Burk 1964), and it appears in the Manitoba escarpment as the lowest few meters of the Belle Fourche Member of the Ashville Formation (McNeil and Caldwell 1981, p. 48-50, text-fig. 11). These lowest few meters contain the Verneuilina canadensis foraminiferal fauna which marks the lowest subzone of the $M$. manitobensis Zone of Late Albian Age.

Seemingly conformable, overlying beds of the Belle Fourche Member contain the Verneuilinoides perplexus foraminiferal fauna which distinguishes the zone of that name of Middle to Late Cenomanian Age. Hence in the Manitoba escarpment and across most of the southern Interior Plains, the Haplophragmoides postis goodrichi Subzone and the Haplophragmium swareni Subzone of the $M$. manitobensis Zone and the entire $T$. alcesensis Zone are missing. Stelck et al. (1958, p. 13) first proposed that the 'fish-scale marker' may mark an unconformity. North and Caldwell (1975, p. 315) and Caldwell et al. (1978, p. 520) suggested the marker may denote a horizon of regional paraconformity. In northeastern British Columbia, where the Verneuilina canadensis Subzone of the $M$. manitobensis Zone contains ammonites, it corresponds to the lower part of the $N$. haasi Subzone of the Neogastroplites Zone. Hence, if the late Albian-Early Cenomanian foraminiferal zones are chronostratigraphically reliable across the southern Interior Plains, the 'fish-scale marker' must be diachronous in addition to containing one or more paraconformities.

The Late Albian was a time of shrinking of the Western Interior seaway as the regressive phase of the Kiowa-Skull Creek marine cycle reached its acme. Unconformities, usually expressed as disconformities, tend to be concentrated in deposits of the regressive maxima, and commonly a number of these disconformities when traced eastwards are found to anastomose into a single discontinuity of considerable temporal magnitude (Kauffman 1977, p. 89; Kauffman et al. 1977, p. 3, 4, fig. 2). Such circumstances may explain the loss of Late Albian-Early Cenomanian section eastwards from northeastern British Columbia, across the southern Interior Plains, to the Manitoba escarpment, although obvious erosional surfaces have not been identified.

\section{Stage boundaries within the Upper Cretaceous Series}

Just as the position of the Albian-Cenomanian boundary can be reliably established in the continuous foraminfer- and mollusc-bearing sections of the western flank of the basin and becomes enclosed eastward in an expanding depositional hiatus, the same is true in more or less degree of the Cenomanian-Turonian, Turonian-Coniacian, Coniacian-Santonian, and Santonian-Campanian boundaries. Not only are the sections of the eastern platform (foreland bulge) of the basin less complete than those of the western foredeep in Canada, they are markedly less complete than those of the eastern platform in the United States (fig. 2), where Kauffman et al. (1977) established their series of detailed zones and substages within the Late Albian-Late Coniacian succession. Some local disconformities, which map regionally in the Manitoba escarpment and adjacent plains as weak angular unconformities must be attributed to tectonic effects probably linked to the developing Rocky Mountains far to the west. Other disconformities and paraconformities may be expressions of non-deposition or, locally, of 
submarine erosion or sedimentary by-pass. Whatever their cause, they diminish the value of Late Cenomanian to Early Campanian sections in the eastern plains for refining criteria that would aid in delineation of the intervening stage boundaries.

Based on molluscs, Jeletzky (1968, fig. 2) drew the Cenomanian-Turonian boundary at the top of Dunveganoceras Zone of Warren and Stelck (1940). In 1971 (fig. 3), he raised the position slightly, almost to the base of his Watinoceras and Inoceramus labiatus Zone, including beds with Sciponoceras gracile (an important marker of the boundary farther south in the United States) in the Turonian Stage. Cobban (in Obradovich and Cobban 1975, Tab. 1) placed the boundary slightly higher still, at the base of the Watinoceras coloradoense Zone or Inoceramus labiatus (sensu lato) Zone and above the $S$. gracile Zone. Most workers seem to have accepted Cobban's position. The most continuous sedimentary sequence through the Cenomanian-Turonian boundary in the southern Interior Plains again seems to be that in the Peace River district of northwestern Alberta and northeastern British Columbia where all the key molluscan elements required to establish the boundary seem to be present (Stelck and Wall 1955, p. 6-28; Jeletzky 1968, p. 25-27). Farther east, across the plains, elements of the Dunveganoceras and $S$. gracile Zones have not been found.

In the Peace River district, the boundary falls within the foraminiferal Zone of Flabellammina gleddiei, which ranges from within the Dunveganoceras albertense Zone to within the $W$. coloradoense Zone of Cobban. The $F$. gleddiei fauna is known only from the Peace River drainage basin, and its absence from other parts of the Rocky Mountain foothills and from the plains is not easily explained. Distribution of the fauna may have been constrained by certain environmental factors, but this is difficult to accept given the known distribution of other similar faunas in the region and the expanding marine conditions of Late Cenomanian-Early Turonian time when the transgressive phase of the Greenhorn marine cycle or $T_{6}-R_{6}$ global cycle of Kauffman (1977, p. 89 , fig. 7) was nearing its acme. Alternatively, the fauna may have been much more widely distributed and its wider record subsequently obliterated. A disconformity, pronounced in its effect in mid-Saskatchewan where it brings the Early Turonian foraminiferal Zone of Hedbergella loetterlei to rest on beds as old as those of the Late Albian Miliammina manitobensis Zone, may be more regional in its effect and account for absence of the $F$. gleddiei deposits from the plains. Such a disconformity also could explain why elements of the Dunveganoceras and $S$. gracile molluscan zones have not been recovered from so much of the plains. At present, throughout most of the plains, the Early Turonian $H$. loetterlei Zone, marking the most widespread marine conditions of the Greenhorn marine cycle, rests on the early Late Cenomanian Verneuilinoides perplexus Zone, and there is no sign of the $F$. gleddiei Zone between them. Like the AlbianCenomanian boundary, therefore, the Cenomanian-Turonian boundary may coincide largely with a paraconformable surface.

Jeletzky (1968, fig. 2; 1971, fig. 3) drew the Turonian-Coniacian boundary to coincide with that between his Scaphites preventricosus-Inoceramus deformis Zone and his $S$. ventricosus-I. involutus Zone, and the Coniacian-Santonian boundary to coincide with that between the latter. zone and his $S$. depressus Zone. Cobban (in Obradovich and Cobban 1975, tab. 1), with some hesitation, placed the Turonian-Coniacian boundary a little lower, between the $S$. corvensis Zone and the $S$. preventricosus-I. deformis Zone and concurred on the position of the ConiacianSantonian boundary. There is growing support for including occurrences of $S$. preventricosus and I. deformis within the Coniacian Stage (see, for example, Kauffman et al. 1977, p. 8-12). The key scaphitid and inoceramid molluscs for discrimination of these inter-stage boundaries have been found in the Rocky Mountain foothills and immediately adjacent plains, but not farther east across most of the basin (Jeletzky 1968, p. 32, 33).

Among the foraminiferal faunas of Turonian, Coniacian, and Santonian Age, two are of unusual importance because they are composed largely or wholly of planktonic elements. These are the Hedbergella loetterlei fauna, which distinguishes an Early Turonian zone, and the Globigerinelloides sp. fauna, which distinguishes a Santonian zone (although the ages of the lowest and highest beds carrying the fauna in places may be slightly older and slightly younger). These zones mark the times during the Greenhorn and 


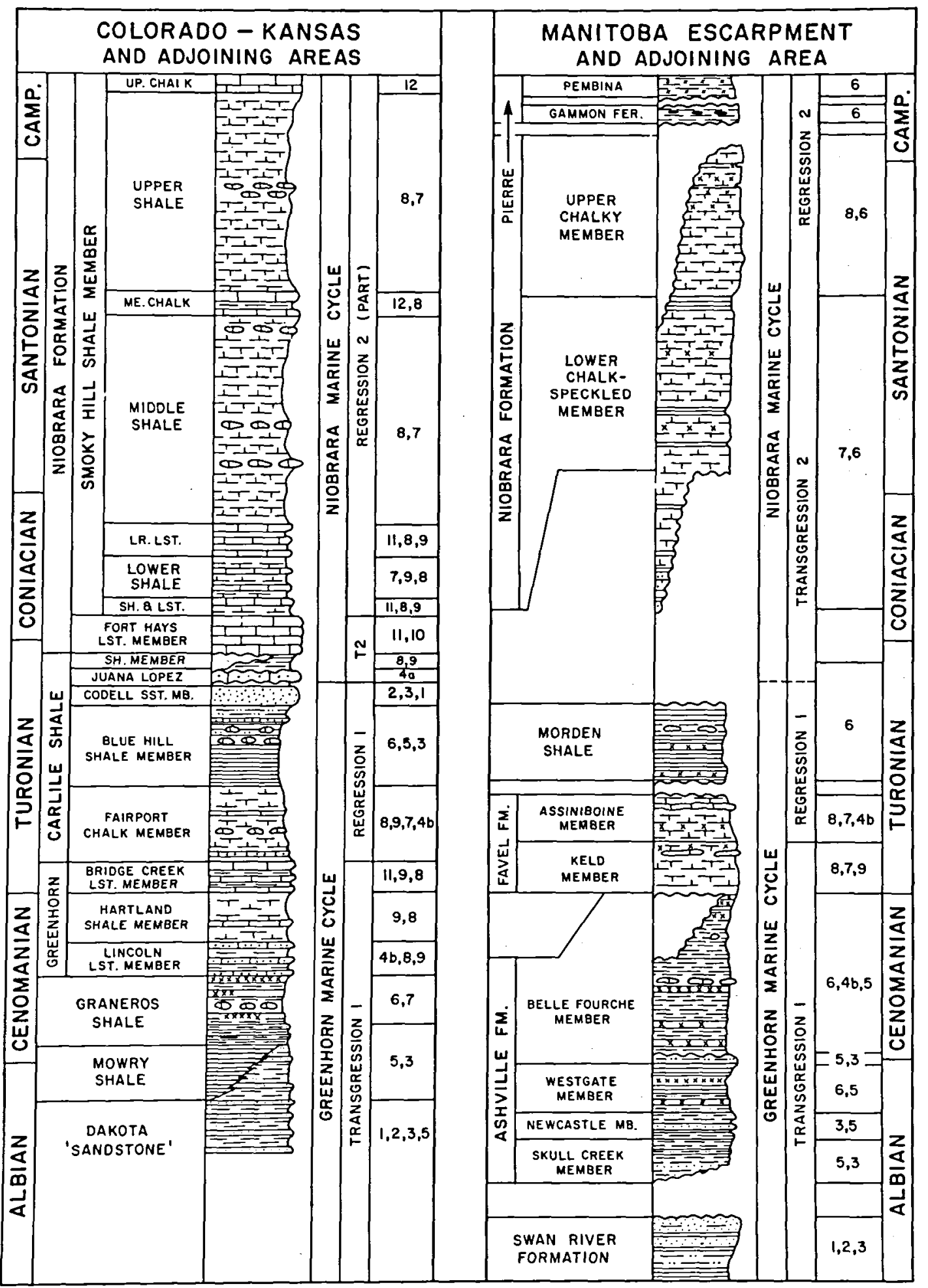

Figure 2. Comparison of a largely pre-Campanian composite section for the mid-basin of the Western Interior of the United States (left side) with that for the Manitoba escarpment and adjacent plains of the Western Interior of Canada (right side), both sedimentary successions deposited on the Eastern Flank of the unitary Western Interior basin during the Greenhorn and Niobrara marine cycles. Columns of numbers to the right of each section refer to the lithotype numbers of Kauffman (1967, p. 87-89), the lowest number indicating marginal-marine sandy sediments, the highest number off-shore highly calcareous sediments, and intermediate numbers sediments of gradually decreasing grain-size and increasing calcareous content. The two sections are similar lithologically, although the Canadian section lacks the most calcareous lithotypes.

Note the discontinuous character of the Canadian section, and how many of the stage boundaries fall within hiati and, therefore, coincide with planes of unconformity (mainly of disconformity and paraconformity). Data for the section in the United States modified after Kauffman (1967, fig. 2).

Reproduced with permission of the Geological Association of Canada. 
succeeding Niobrara marine cycles when warmer waters spread northward within the Western Interior seaway to flood the basin to its limits, bringing with them subtropical elements of the Southern Interior Subprovince (Kauffman 1977, p. 91, 92). The $H$. loetterlei and Globigerinelloides sp. faunas and their biostratigraphic implications have been fully discussed by Caldwell et al. (1978, p. 526-529, 534-542). Deposits of the regressive phase of the Greenhorn marine cycle and transgressive phase of the Niobrara marine cycle fall within three, intervening foraminiferal zones, the Pseudoclavulina sp. Zone, the Trochammina sp. Zone, and the Bullopora laevis Zone. These have less distinctive faunas and are confined mainly to the Rocky Mountain foothills and adjacent plains of southern Alberta. It is these zones that contain the Turonian-Coniacian and Coniacian-Santonian boundaries. Farther east, across Saskatchewan, these zones are missing, and a major disconformity brings the Globigerinelloides $\mathrm{sp}$. Zone to rest directly on thinned remnants of the $H$. loetterlei Zone. The hiatus diminishes through Manitoba and, in the Manitoba escarpment, a thin shale carries elements of the Pseudoclavulina sp. fauna and possibly also of the Trochammina sp. fauna. Once again, therefore, like the two preceding inter-stage boundaries, the Turonian-Coniacian and Coniacian-Santonian horizons are reliably established only on the western flank of the basin, where complete, or near complete, foraminiferal and molluscan zonal sequences are preserved. If the boundary between the $S$. corvensis Zone and the $S$. preventricosus-I. deformis Zone is taken as the Turonian-Coniacian boundary, then that horizon lies high in the foraminiferal Zone of Pseudoclavulina sp. The Coniacian-Santonian boundary lies in the lower part of the foraminiferal Zone of $B$. laevis, which spans the upper $S$. ventricosus-I. involutus Zone and the $S$. depressus Zone (Caldwell et al. 1978, p. 529-534).

In terms of molluscan biostratigraphy, there is no disagreement about the position of the Santonian-Campanian boundary. Jeletzky (1968, fig. 2; 1971, fig. 3) drew it at the top of the Zone of Desmoscaphites spp. and base of the succeeding Zone of Hoploscaphites hippocrepis. Cobban (in Obradovich and Cobban 1975, tab. 1) drew it at the top of the Zone of Desmocaphites bassleri which is coincident with the base of the Zone of
Scaphites hippocrepis. There seemed to be little problem in defining the boundary also in terms of foraminiferal zones when these were first established. In the southern Rocky Mountain foothills, the upper Heterohelix cf. $H$. reussi Subzone of the Globigerinelloides sp. Zone falls within the Desmoscaphites spp. Zone of Jeletzky and certainly within the $D$. erdmanni Zone and possibly also the D. bassleri Zone of Cobban. Farther east, across the plains, the succeeding foraminiferal Zone of Trochammina ribstonensis ranges from at least the upper part of the $S$. hippocrepis Zone to the Zone of Baculites $o b$ tusus. The inter-stage boundary, therefore, lay between the two foraminiferal zones. In the Manitoba escarpment, however, McNeil and Caldwell (1981, p. 100) reported Baculites (?)thomi from the upper part of the Gavelinella henbesti Subzone of the Globigerinelloides sp. Zone and $B$. thomi corresponds in range to the $D$. erdmanni and $D$. bassleri zones. As the $H$. cf. $H$. reussi Subzone succeeds the $G$. henbesti Subzone in the Manitoba escarpment, it seems likely that the higher subzone is in part at least Early Campanian in age. In keeping with such a conclusion, the Trochammina ribstonensis Zone in the Manitoba escarpment has been inferred to lie in the Zones of $B$. obtusus to $B$. perplexus. It is distinctly possible, therefore, that the Globigerinelloides sp. Zone and overlying Trochammina ribstonensis Zone may be slightly diachronous across the southern Interior Plains, and the Santonian-Campanian boundary may lie between the zones on the western flank of the basin and in the upper part of the Globigerinelloides sp. Zone on the eastern flank of the basin. The suggestion of a disconformity between the Globigerinelloides sp. Zone and the T. ribstonensis Zone across much of the plains (North and Caldwell 1975, p. 321; Caldwell et al. 1978, p. 539) adds further complication. The disconformity has been assumed to lie at the top of the Santonian section and to be an expression of the Santonian-Campanian discontinuity previously recognized in many other parts of the Western Interior basin. The break now may be correlated with the regressive acme of the Niobrara or $T_{7}-R_{7}$ global cycle of Kauffman (1977, p. 89, fig. 7). It is entirely possible, however, that the short-lived withdrawal of the sea at the close of Niobrara deposition did not take 
place until Early Campanian time and, if the disconformity extends across all or most of the southern Interior Plains, it may obfuscate at any locality a precise reading of the Santonian-Campanian boundary in terms of both foraminiferal and molluscan zones.

Cobban (in Obradovich and Cobban 1975, p. $47-49$, tab. 1) discussed various positions, based on ammonites and foraminifers, in which the Campanian-Maastrichtian boundary had been drawn in the Western Interior basin. He gave reasons for revising its position from the base of the ammonite Zone of Baculites baculus, which like Jeletzky (1971, fig. 3) he previously had favoured, to one coincident with the base of the $B$. reesidei Zone. This position has won growing acceptance. It corresponds to a level slightly above the base of the foraminiferal Zone of Anomalinoides sp. (Caldwell et al. 1978, p. 558561). The boundary can be drawn precisely in the South Saskatchewan River valley (Caldwell 1968; North and Caldwell 1970), where the stratotype of the Anomalinoides sp. Zone is located and where a continuous sequence of Cobban's baculitid zones has been recognized.

The Anomalinoides fauna, one of the most diverse and rich assemblages of benthonic species in the entire Upper Cretaceous Series, thrived when the Western Interior seaway remained expanded following the transgressive peak of the Bearpaw marine cycle or $T_{9}-R_{9}$ global marine cycle of Kauffman (1977, p. 89, fig. 7). Many elements described from the Gulf Coast, and thus from the Southern Interior biogeographic province, are included in the fauna. Although diversity drops toward the western margin of the seaway, the fauna remains recognizable across the western half of the basin where it occurs in association with baculitids of the $B$. cuneatus to $B$. jenseni Zones (Caldwell 1982, figs. 8, 9). Eastwards from the South Saskatchewan River valley, pre-Pleistocene erosion has removed the Campanian-Maastrichtian boundary beds from wide tracts of the plains.

The Western Interior seaway withdrew finally from what is now the southern Interior Plains of Canada in Early Maastrichtian ( $B$. grandis) times. Hence the Maastrichtian-Paleocene boundary is established on quite different palaeontological criteria (ones that are excluded from consideration in this synopsis) from those used to establish the underlying inter-stage boundaries. The Cretaceous-Tertiary (Maastrichtian-Paleocene) boundary is the subject of a voluminous literature on its own.

\section{Conclusions}

Broad gradations have been recognized in the facies and faunas of Cretaceous marine sequences throughout the Western Interior basin of North America. The gradations stem from differences in palaeoclimate and palaeogeography and from the variable influence of regional tectonics in time and place.

In contrast with the Western Interior of the United States, Berriasian to Aptian rocks are developed, and Albian rocks much more extensively developed, in marine facies in the southern Western Interior of Canada. Berriasian, Valanginian, Upper Barremian, and Aptian rocks, although thickly developed in northwestern Alberta and northeastern British Columbia, have yielded few foraminifers and molluscs, and discrimination of the stage and substage boundaries (solely on molluscs) remains tentative. The same region, however, offers a complete section through the Albian Stage and into the Cenomanian Stage, with an unmatched, well-documented sequence of ammonite and foraminiferal zones. Central to an understanding of the Albian Stage within the Boreal realm, the section would be a most suitable continental standard.

As for the Early Cretaceous, sedimentation during the Late Cretaceous Epoch was most continuous in the western foredeep of the basin. Albian and post-Albian stage boundaries are most reliably drawn in western sections using the zonal framework based on ammonites and inoceramid bivalves. The boundaries also may be interpreted in terms of zones based on assemblages of (mainly) benthonic foraminifers, although the foraminiferal zones (some of which may be weakly diachronous) usually span several molluscan zones and many of them also span stage boundaries. In more easterly segments of the basin, sedimentation was repeatedly interrupted, and disconformities and paraconformities are rife. In most known sections across the plains, the Albian-Cenomanian, Cenomanian-Turonian, Turonian-Coniacian, Coniacian-Santonian, and 
Santonian-Campanian boundaries are enclosed by hiati.

Continuous, heavier sedimentation (to be correlated with intensifying proto-Laramide tectonics) marks the Campanian Stage and Maastrichtian Stage across the plains. The Campanian-Maastrichtian boundary may be precisely discriminated in western Saskatchewan, in terms of both ammonite and foraminiferal zones, and traced across the western half of the basin. The Maastrichtian-Paleocene boundary is preserved only in continental deposits.

\section{Dansk sammendrag}

Kridttidens etagegranser $i$ den sydlige del af Canadas "Interior Plains" beskrives og diskuteres, og der gives en oversigt over definition af grænserne på grundlag af de vigtigste grupper af index-fossiler. Etagegrænserne er $\mathrm{i}$ dette område primært baseret på den stratigrafiske udbredelse af ammoniter og inoceramer. Zoner baseret på bentoniske foraminiferer og, undtagelsesvis, planktoniske foraminiferer supplerer ammonit- og inoceram-zoneringen, men er ikke så anvendelige, da disse zoner spænder over længere tidsrum og yderligere er svagt diakrone.

\section{References}

Caldwell, W. G. E., 1982. The Cretaceous System in the Williston basin - a modern appraisal. Proc. Fourth Internat. Williston Basin Sympos., Regina, Sasks. Geol. Soc., 295-312.

Caldwell, W. G. E., North, B. R., Stelck, C. R., and Wall, J. W., 1978. A foraminiferal zonal scheme for the Cretaceous System in the Interior Plains of Canada. In Stelck, C. R. and Chatterton, B. D. E. (eds.), Western and Arctic Canadian Biostratigraphy, Geol. Assoc. Canada, Spec. Paper $18,495-575$.

Chamney, T. P., 1973. Microfauna of Gething Formation. In Stott, D. F., Lower Cretaceous Bullhead Group between Bullmoose Mountain and Tetsa River, Rocky Mountain foothills, northeastern British Columbia. Geol. Survey Canada, Bull. 219, 67-71.

Eicher, D. L., 1960. Stratigraphy and micropaleontology of the Thermopolis Shale. Peabody Mus. Nat. Hist., Yale Univ., Bull. $15,126 \mathrm{p}$.

Eicher, D. L., 1965. Foraminifera and biostratigraphy of the Graneros Shale. Jour. Paleontology, 39, 875-909.

Eicher, D. L., 1966. Foraminifera from the Cretaceous Carlile Shale of Colorado. Cushman Found. foram. Research, 17, 16-31.

Eicher, D. L., 1967. Foraminifera from Belle Fourche Shale and equivalents, Wyoming and Montana. Jour. Paleontology, 41, 167-188.

Eicher, D. L. and Worstell, P., 1970. Cenomanian and Turonian Foraminifera from the Great Plains, United States. Micropaleontology, 16, 269-324.

Jeletzky, J. A., 1964. Lower Cretaceous marine index fossils of the sedimentary basins of western and Arctic Canada. Geol. Survey Canada, Paper 64-11, 100 p.
Jeletzky, J. A. 1968. Macrofossil zones of the marine Cretaceous of the Western Interior of Canada and their correlation with the zones and stages of Europe and the Western Interior of the United States. Geol. Survey Canada, Paper 67-72, $66 \mathrm{p}$.

Jeletzky, J. A., 1970. Cretaceous macrofaunas. In Douglas, R. J. W. (ed.), Geology and Economic Minerals of Canada. Geol. Survey Canada, Econ. Geol. Rept. 1, 5th ed., 649-662.

Jeletzky, J. A., 1971. Marine Cretaceous biotic provinces and paleogeography of western and Arctic Canada, illustrated by a detailed study of ammonites. Geol. Survey Canada, Paper 70-22, $92 \mathrm{p}$.

Jeletzky, J. A., 1980. New or formerly poorly known, biochronologically and paleobiogeographically important gastroplitinid and cleoniceratinid (Ammonitida) taxa from Middle Albian rocks of mid-western and Arctic Canada. Geol. Survey Canada, Paper 79-22, 63 p.

Jeletzky, J. A. and Stelck, C. R., 1981. Pachygrycia, a new Sonneratia-like ammonite from the Lower Cretaceous (earliest Albian?) of northern Canada. Geol. Survey Canada, Paper 80-20, 25 p.

Kauffman, E. G., 1967. Coloradoan macroinvertebrate assemblages, central Western Interior. In Paleoenvironments of the Cretaceous Seaway in the Western Interior, 67-143. Golden, Colorado School of Mines Spec. Pub.

Kauffman, E. G., 1973. Cretaceous Bivalvia. In Hallam, A., (ed.), Atlas of Paleobiogeography, 353-383. New York, Elsevier Scietific Publishing Co.

Kauffman, E. G., 1977. Geological and biological overview: Western Interior Cretaceous basin. Mountain Geologist, $14,75-99$.

Kauffman, E. G., 1979. Cretaceous. In Treatise on Invertebrate Paleontology, pt. A, Introduction, A418-A487. Boulder, Colorado, Geol. Soc. America and Univ. Kansas Press.

Kauffman, E. G., Cobban, W. A., and Eicher, D. L., 1977. Albian through Lower Coniacian strata, biostratigraphy and principal events, Western Interior United States. Proc. Second Internat. Conf. Mid.Cretaceous Events, Spec. v., Ann. Mus. Hist. Nat., Nice, France, 21-1 to 21-33.

McNeil, D. H. and Caldwell, W. G. E., 1981. Cretaceous Rocks and Their Foraminifera in the Manitoba Escarpment. Geol. Assoc. Canada, Spec. Paper 21, 439 p.

North American Commission on Stratigraphic Nomenclature, 1983. North American Stratigraphic Code. Bull. Amer. Assoc. Petrol. Geologists, 67, 841-875

North, B. R., and Caldwell, W. G. E., 1975. Foraminiferal faunas of the Cretaceous System in Saskatchewan. In Caldwell, W. G. E., (ed.), The Cretaceous System in the Western Interior of North America, Geol. Assoc. Canada, Spec. Paper 13, 303-331.

Obradovich, J. D., and Cobban, W. A., 1975. A time-scale for the late Cretaceous of the Western Interior of North America. In Caldwell, W. G. E., (ed.), The Cretaceous System in the Western Interior of North America. Geol. Assoc. Canada, Spec. Paper 13, 31-54.

Rudkin, R. A., 1964. Lower Cretaceous. In McCrossan, R. G. and Glaister, R. P. (eds.), Geological History of Western Canada. Calgary, Alberta. Soc. Petrol. Geologists, 156168.

Stelck, C. R., and Wall, J. H., 1965. Foraminifera of the Cenomanian Dunveganoceros Zone from Peace River area of western Canada. Res. Coun. Alberta, Rept. 70, 1-6.

Stelck, C. R., Wall, J. H., and Wetter, R. E., 1958. Lower Cenomanian Foraminifera from Peace River area, western Canada. Res. Coun. Alberta, Geol. Div., Bull. 2, p. I, 1-35. 
Stott, D. F, 1975. The Cretaceous System in northeastern British Columbia. In Caldwell, W. G. E., (ed.), The Cretaceous System in the Western Interior of North America. Geol. Assoc. Canada, Spec. Paper 13, 441-467.

Stott, D. F., 1982. Lower Cretaceous Fort St. John Group and Upper Cretaceous Dunvegan Formation of Mackenzie and Yukon Territory. Geol Survey Canada, Bull. 328, 124 p.

Warren, P. S., and Stelck, C. R., 1940. Cenomanian and Turonian faunas in the Pouce Coupe district, Alberta and British Columbia. Trans. Roy. Soc. Canada, ser. 3, sect. 4, 34, 143-152.

Warren, P. S., and Stelck, C. R., 1958. Lower Cenomanian Ammonoidea and Pelecypoda from Peace River area, western Canada. Res. Coun. Alberta, Geol. Div., Bull. 2, 36-51.
Warren, P. S., and Stelck, C. R., 1969. Early Neogastroplites, Fort St. John Group, western Canada. Bull. Can. Petrol. Geology, 17, 529-547.

Williams, G. D., and Burk, C. F., Jr., 1964. Upper Cretaceous. In McCrossan, R. G. and Glaister, R. P., (eds.), Geological History of Western Canada. Calgary, Alberta Soc. Petrol. Geologists, 169-189.

Williams, G. D., and Stelck, C. R., 1975. Speculations on the Cretaceous paleogeography of North America. In Caldwell, W. G. E., (ed.), The Cretaceous System in the Western Interior of North America. Geol. Assoc. Canada, Spec. Paper 13, 1-20. 